\title{
Modulation of alternative splicing of adenoviral E1A transcripts: factors involved in the early-to-late transition
}

\author{
Renata Gattoni, Karim Chebli, Michèle Himmelspach, and James Stévenin ${ }^{1}$ \\ Unité 184 de Biologie Moléculaire et de Génie Génétique de l'Institut National de la Recherche Médicale, Laboratoire de \\ Génétique Moléculaire des Eucaryotes du Centre National de la Recherche Scientifique, Institut de Chimie Biologique, \\ Faculté de Médecine, 67085 Strasbourg, Cédex, France
}

\begin{abstract}
The E1A pre-mRNA of adenovirus is spliced into three mRNA species (13S, 12S, and 9S mRNAs) by the use of three alternative 5 '-splice sites. The $13 \mathrm{~S}$ and $9 \mathrm{~S}$ mRNAs predominate during the early and late periods of infection, respectively. With HeLa nuclear extracts isolated in early and late periods of infection, we were able to reproduce a 13S-9S modulation that resembles that occurring in infected cells. An in vitro analysis of the cis-acting parameters involved in the 13S-9S switch indicates that the 13S mRNA splicing inhibition is one of the first events of the late period and leads to the subsequent stimulation of the 9S mRNA reaction. The new abilities of the late nuclear extract for the 9S mRNA reaction were also confirmed by analyzing splicing of a major late transcript containing leaders 1 and 2 separated by the wild-type intervening sequence (IVS) of 1021 nucleotides. Complementation experiments show that the trans-acting factor(s) are micrococcal nuclease sensitive. They were partially characterized by induction experiments, and we show that the primary factors responsible for the 13S-9S modulation in vitro are viral RNAs of high molecular weight that accumulate late in infection. We postulate that the splicing modulation of E1A pre-mRNA results from an indirect mode of action for these viral RNAs, based on a sequestration of common splicing factors that are not present in vast excess in HeLa cells.
\end{abstract}

[Key Words: Alternative splicing; cis-acting factors; trans-acting factors; splicing modulation; adenoviral ElA; pre-mRNA]

Received February 18, 1991; revised version accepted August 12, 1991

Pre-mRNA alternative splicing is a mechanism of widespread importance for regulating gene expression and generating isoform diversity. Basically, in constitutive splicing, invariant pairs of $5^{\prime}$ - and $3^{\prime}$ 'splice sites are selected to produce a single mRNA, whereas alternative splicing results from the competitive use of alternative splice sites to produce multiple mRNA species (for reviews, see Leff et al. 1986; Breibart et al. 1987; Smith et al. 1989/. Alternative splicing occurs by a variety of modes. Exclusion of whole exons, as in the troponin $T$ gene (Cooper and Ordahl 1985), competitive choice between adjacent $5^{\prime}$-splice sites as in adenoviral E1A (Berk and Sharp 1978), or between adjacent 3'-splice sites as in the transformer gene of Drosophila (Boggs et al. 1987) seem to be relatively simple processes. In contrast, the existence of mutually exclusive exons as in the $\alpha$ - or $\beta$-tropomyosin gene (Helfman et al. 1986; Wieczorek et al. 1988; Libri et al. 1989) apparently results from a coordinate choice of different specific pairs of splice signals and appears to be more complicated.

Another interesting aspect of the alternative splicing

${ }^{1}$ Corresponding author. is that it may be regulated or modulated. Examples have been observed for some adenovirus genes during the course of infection (for review, see Ziff 1980). However, splicing of cellular genes has also been shown to be regulated tissue specifically as in the CGRP gene (Crenshaw et al. 1987; Leff et al. 1987), at specific developmental stages as in the troponin $\mathrm{T}$ gene (Cooper and Ordahl 1985), or sex specifically (for review, see Hodgkin 1989). These examples strongly suggest the requirement of trans- acting factors that would control the various alternative splicing patterns. The existence of trans-acting factors also implies that they have targets somewhere on the pre-mRNA sequences subject to alternative splicing. The analysis of the couples of trans-acting and cis-acting factors engaged in the regulation or modulation of all of a series of pre-mRNAs is fundamental because it is likely that all kinds of mechanisms have been utilized by the cellular machinery.

Some information is available concerning the cis-acting elements involved, and it has been shown that intron sequences (Arrigo and Beemon 1988), exon sequences (Cooper and Ordahl 1989; Streuli and Saito 1989), intron spacing (Fu and Manley 1987; Smith and Nadal-Ginard 
1989), or secondary structures (Eperon et al. 1988; Chebli et al. 1989; Libri et al. 1990) may be involved in the definition of alternative splicing. However, much less information is available on the trans-acting factors, except in the case of the determination of sex in Drosophila for which the putative factors are well defined (Burtis and Baker 1989; Goralski et al. 1989; Bell et al. 1991). Nonetheless, it is possible that some constitutive splicing factors may be the basis of some types of splicing modulation. For instance, protein factors have been shown to play a role in differential splicing /Ge and Manley 1990; Krainer et al. 1990b) and a similar role has been proposed for subspecies of U small nuclear ribonucleoprotein (snRNP) (Sharpe et al. 1989; Bach et al. 1990).

The ElA pre-mRNA of adenovirus is a short substrate, alternatively spliced mainly through the excision of a unique intron of varying size (Berk and Sharp 1978; Chow et al. 1979|. The utilization of three alternative 5 '-splice sites and a common $3^{\prime}$-splice site results in the formation of $13 \mathrm{~S}, 12 \mathrm{~S}$, and $9 \mathrm{~S}$ mRNAs. During lytic infection, these mRNA species accumulate differently, the $13 \mathrm{~S}$ and the $9 \mathrm{~S}$ forms being the most abundant during the early and late periods, respectively (Spector et al. 1978; Chow et al. 1979; Svensson et al. 1983). Although changes in the half-life of different viral mRNAs might account for differential accumulation of mRNA species in the cytoplasm (Wilson and Darnell 1981), it has been shown that modulation of alternative splicing is also responsible for this phenomenon (Montell et al. 1984). Using nuclear extracts prepared from infected HeLa cells in early and late periods of infection, we were able to reproduce a $13 \mathrm{~S}-9 \mathrm{~S}$ modulation that is very similar to that occurring during the early-to-late transition. Analysis of cis-acting parameters shows that the $13 \mathrm{~S}$ mRNA inhibition is a primary event of the late period of infection that allows the subsequent stimulation of $9 \mathrm{~S}$ mRNA splicing. Analysis of the trans-acting factors involved in the $13 \mathrm{~S}$ 9S modulation indicates that nucleic acids of viral origin are the initial elements that promote this modulation.

\section{Results \\ Splicing abilities of nuclear extracts isolated from adenovirus-infected HeLa cells}

We developed previously an in vitro splicing system with nuclear extracts isolated from uninfected HeLa cells, which are able to promote alternative splicing of E1A pre-mRNA of adenovirus (Schmitt et al. 1987). We showed that under appropriate ionic conditions, the wild-type ElA substrate is predominantly spliced into 13S mRNA, whereas the 9S mRNA reaction is very minor, similar in extent to that occurring during the early period of infection. To follow in vitro the ElA splicing modulation that occurs during the infection cycle, nuclear extracts were prepared from infected HeLa cells isolated in the early period ( $5 \mathrm{hr}$ postinfection) or in the late period of infection $(10,12$, and $15 \mathrm{hr}$ postinfection). These extracts have very similar biochemical characteristics, except for an increase of $10-25 \%$ of total nucleic acid concentration in late extracts and for the presence of virus-associated small RNA and a low amount of viral structural proteins.

The abilities of early and late nuclear extracts to splice the Sp4 transcript, which covers the vast majority of the E1A unit, were assessed by gel analyses of splicing products formed after 0.5 - and 2-hr incubations with the different extracts (Fig. 1). The pattern of splicing obtained with the early extract (Fig. 1, lanes b,c) resembles that described with uninfected HeLa nuclear extract (data not shown), as the $13 \mathrm{~S}$ mRNA reaction is very efficient; whereas the $9 S$ reaction, which is best assessed by following the 95 intervening sequence (IVS) accumulation, occurs only at a low level. In contrast, the extracts iso-

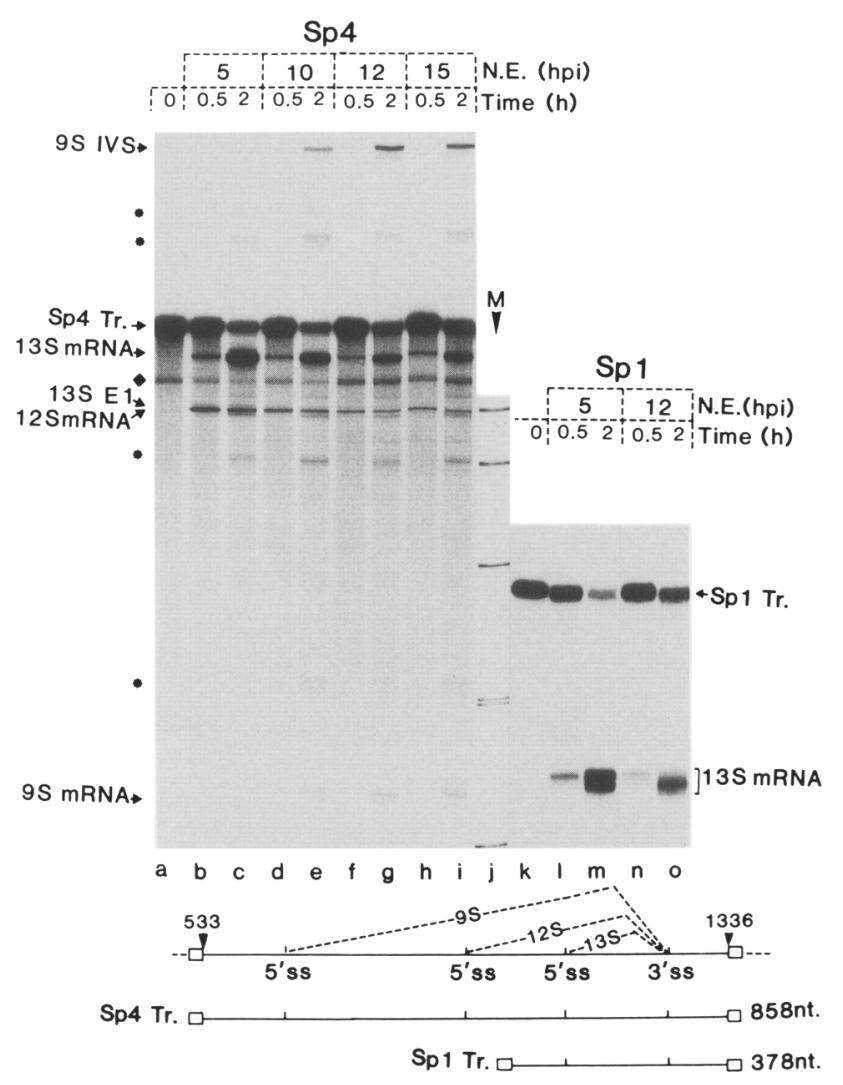

Figure 1. Modulation of in vitro ElA splicing with nuclear extracts isolated from adenovirus-infected cells. The Sp4 (left) and Spl (right) transcripts were processed with nuclear extracts isolated from infected cells at $5,10,12$, and $15 \mathrm{hr}$ postinfection (hpi) in splicing conditions for 0.5 and $2 \mathrm{hr}$, and the RNA products were analyzed on denaturing gel. The transcripts and the splicing products of the $13 \mathrm{~S}, 12 \mathrm{~S}$, and $9 \mathrm{~S}$ mRNA reactions detected on the gel are indicated alongside. Note that the $12 \mathrm{~S}$ mRNA reaction is under-represented during in vitro splicing assays, as mentioned previously (Schmitt et al. 1987). ( ) Prematurely terminated transcripts; $\left(^{*}\right)$ the splicing products resulting from the minor 216-nucleotide intron reaction (Gattoni et al. 1988). The markers (M) in lane $j$ are $M s p I$ fragments of pBR322 DNA. The diagrams (bottom) show the exon/intron organization of the Sp4 plasmid and the schematic structure of the Sp4 and Spl transcripts. (口) pSP65 sequences present at the ends of ElA sequences. 
lated in the late period of infection carry out the 13S reaction with lower efficiency, whereas the 9S IVS accumulation reaches its maximal level at $12 \mathrm{hr}$ postinfection. This type of in vitro modulation, which occurs in a similar fashion to that assessed in vivo, was obtained regularly with eight different preparations of early and late extracts, isolated at 5 and $12 \mathrm{hr}$ postinfection. Another representative example of modulation with early and late extracts is given in Figure 2 (Sp4), which shows that the 9S mRNA reaction is about three times more efficient than the 13S mRNA reaction with the late extract, a result paralleling that observed in vivo. Quantification of splicing efficiencies obtained in Figures 1 and 2 and in other experiments indicates that the $13 \mathrm{~S}$ splicing efficiency was reduced $\sim 3-9$ times with late extracts while that of the $9 \mathrm{~S}$ reaction was increased from 3 to $>10$ times. We have verified that the modulation of splicing is not a result of general variations of the concentration of splicing factors within the extracts by analyzing the Sp4 splicing with variable volumes of early and late nuclear extracts (from 7 to $11 \mu \mathrm{l}$ for a $25-\mu \mathrm{l}$ assay, corresponding to a volume variation of $60 \%$ ). Under these conditions, the 13S-9S modulation was always observed with the late extract (data not shown), suggesting that the modulation was the result of a new intrinsic property of this extract.

The early-to-late modulation does not occur with pre-mRNA subject to constitutive splicing

To determine whether the early-to-late modulation ob- served with the ElA transcript is specific, we analyzed how a transcript not subject to alternative splicing is spliced with the early and late extracts. We chose the $\beta$-globin pre-mRNA, which has the advantage of containing two introns, whose sizes (126 and 573 nucleotides, respectively) are very close to those of the $9 \mathrm{~S}$ and $13 S$ introns (114 and 589 nucleotides). Splicing patterns of $\beta$-globin pre-mRNA with early and late nuclear extracts (shown in Fig. 2, right) are similar to those obtained previously (Aebi et al. 1986). The mRNA product of the IVS1 excision (E1:E2: L : E3), the final mRNA (E1 : E2 : E3), and the small (S) and large (L) IVSs are formed with comparable efficiency. The only difference resides in a weak decrease of global efficiency, as evidenced by the higher amount of intact transcript after incubation with the late extract (Fig. 2, lane $t$ ). Therefore, these results indicate that most of the general splicing properties of the late extract are only weakly modified. They also indicate that the splicing modulation obtained with E1A substrates is not primarily related to the difference in sizes of $13 \mathrm{~S}$ and 9S IVSs, because such a modulation is not detected with the $\beta$-globin substrate.

\section{Cis-acting requirements for the E1A splicing modulation}

Because the 13S and 9S splicing reactions are in competition for the processing of E1A pre-mRNA, we have determined how splicing variations for both the $13 \mathrm{~S}$ and $9 \mathrm{~S}$ mRNAs are linked. We first analyzed splicing of the 378-

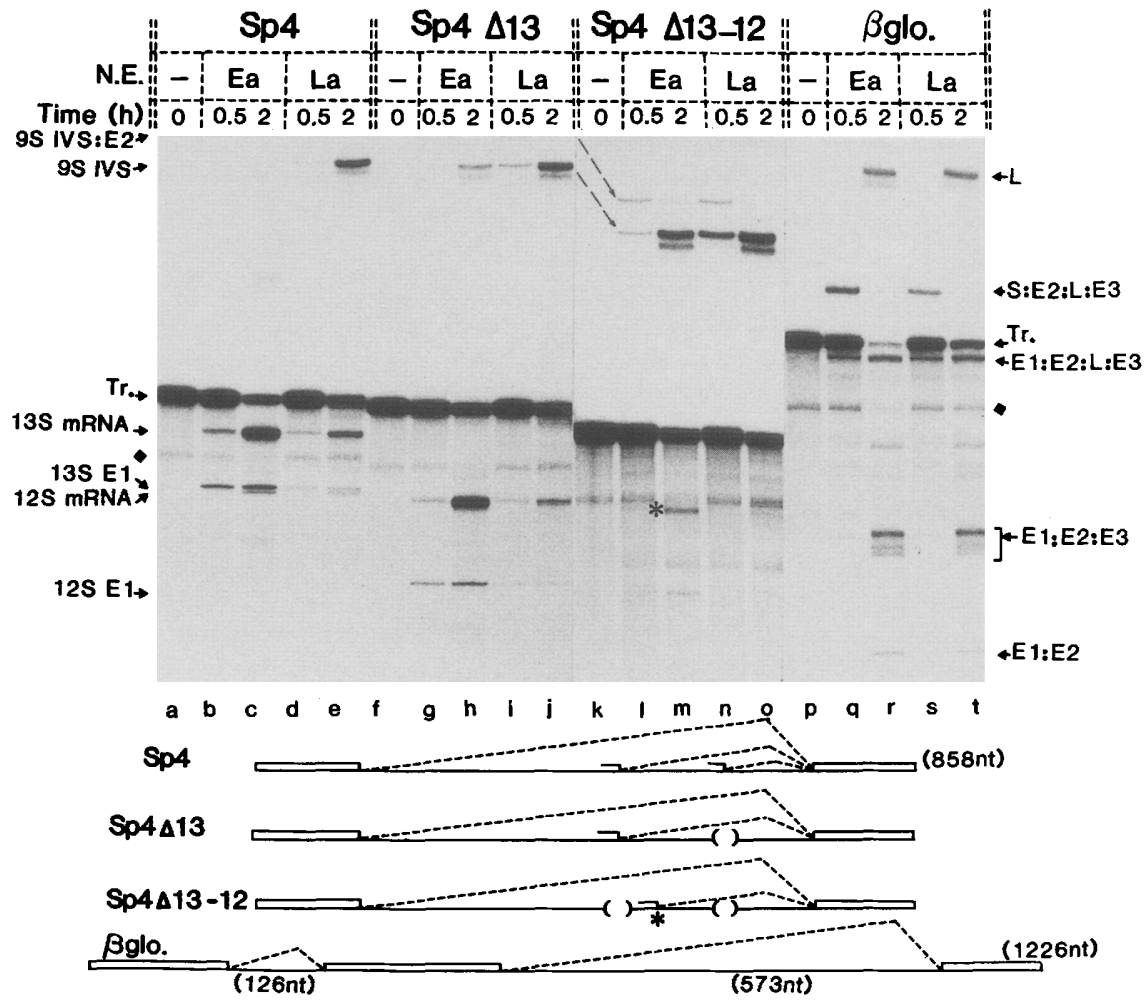

Figure 2. In vitro splicing of $\mathrm{Sp} 4$ and derived transcripts and rabbit $\beta$-globin transcript with early and late nuclear extracts. The wild-type Sp4 transcript $(858$ nucleotides), or Sp4 413 (827 nucleotides) and Sp4s13-12 (752 nucleotides) is submitted to splicing with early $(\mathrm{Ea}, 5 \mathrm{hpi})$ or late $(\mathrm{La}$ 12 hpi) nuclear extract (N.E.). Times of incubation under splicing conditions are indicated above the lanes. The positions of the transcripts and products of the 13S, $12 \mathrm{~S}$, and $9 \mathrm{~S}$ reactions are indicated at left. Within the Sp4 $\Delta 13-12$, arrows indicate the strong modifications of the $9 \mathrm{~S}$ lariat product migrations, and the asterisk $\left({ }^{*}\right)$ indicates the cryptic mRNA. Analysis of splicing with rabbit $\beta$-globin transcript ( $\beta$ glo) is shown at right. The organization of its splicing products is symbolized, with E1, E2, and E3 representing the three exons, and $\mathrm{S}$ and $\mathrm{L}$ denoting the small and large introns, respectively. $(\downarrow)$ The prematurely terminated transcripts. Structures of the substrates are given at bottom. Open bars represent exons; horizontal solid lines denote introns; broken diagonal lines symbolize the different splicing pathways. The beginning of 13S, 12S, and cryptic exons are represented by uncompleted boxes. The 13S and 12S 5'-splice site deletions are indicated with open parentheses. 
nucleotide Spl transcript (Fig. 1), which is a $5^{\prime}$-truncated form of the 858-nucleotide Sp4 transcript and which has lost the $9 \mathrm{~S}$ and $12 \mathrm{~S}$ donor sites. With this transcript, the $13 \mathrm{~S}$ splicing reaction was highly efficient with the early extract but was impaired with the late extract, as demonstrated by the weaker accumulation of the 13S mRNA species of 264 nucleotides (Fig. 1, Sp1). Nevertheless, the inhibition may be less important than that observed with the Sp4 transcript. Thus, the above results indicate that the RNA sequences between 1006 and 1330 of the genome are sufficient to induce a $13 \mathrm{~S}$ splicing modulation. Moreover, the $\mathrm{Spl}$ construction was adequate to analyze whether the $13 \mathrm{~S}, 12 \mathrm{~S}$, and $9 \mathrm{~S} 5^{\prime}$-splice sites, which have different primary sequences and sequence contexts, are primarily involved in the early-to-late modulation of E1A transcripts. For that, we analyzed modified $\mathrm{Sp} 1$ substrates in which the $13 \mathrm{~S} 5^{\prime}$-splice site region was replaced with the corresponding $9 S$ and $12 S$ regions, with the $13 \mathrm{~S} 5^{\prime}$-splice site region also being reinserted to compare homologous constructions. These transcripts were spliced efficiently with an early nuclear extract, and all three exhibited a lowering of splicing efficiency similar to that of the Spl transcript in the presence of the late nuclear extract (data not shown). Thus, this suggests that, taken alone, the primary sequences of the regions encompassing the $13 \mathrm{~S}, 12 \mathrm{~S}$, or $9 \mathrm{~S} 5^{\prime}$-splice sites do not have a primary role in the induction of the $13 \mathrm{~S}-9 \mathrm{~S}$ modulation.

To determine whether the $9 \mathrm{~S}$ reaction stimulation with the late extract is only a consequence of the $13 \mathrm{~S}$ inhibition, we analyzed the splicing of modified Sp4 transcripts, in which only the $13 \mathrm{~S}$, or the $13 \mathrm{~S}$ and $12 \mathrm{~S}$ 5 '-splice sites are deleted. With the early nuclear extract, we observed that deletion of the 13S $5^{\prime}$-splice site in the Sp4 413 transcript promotes a strong stimulation of the $12 S$ mRNA reaction and a weak stimulation of the $9 S$ mRNA reaction (Fig. 2, Sp4s13). However, with the late extract, a 12S-9S modulation occurs, indicating that the $12 S$ mRNA reaction from the Sp4 413 transcript is sensitive to the same kind of cis-acting requirement as the $13 \mathrm{~S}$ mRNA reaction from the wild-type transcript. Finally, when a transcript in which both $13 \mathrm{~S}$ and $12 \mathrm{~S} 5^{\prime}$ splice sites were deleted (Fig. 2, Sp4 13 13-12) was tested, we observed even with the early extract a high stimulation of the 9S mRNA reaction. This demonstrates that in the wild-type or Sp4 413 transcripts, the $13 \mathrm{~S}$ and/or $12 \mathrm{~S}$ mRNA reactions have a strong effect of cis-acting competition on the 9S mRNA reaction. Moreover, an additional stimulation of about twofold for the $9 \mathrm{~S}$ reaction, detected at $30 \mathrm{~min}$ and $2 \mathrm{hr}$ of incubation, occurs with the late extract, suggesting that this extract also possesses new abilities to splice the Sp4 transcript family into 9S mRNA. In addition, with Sp4 13 13-12, the cryptic $5^{\prime}$-splice site CAG/GU at position 1023, described previously (Zhuang and Weiner 1986), was weakly activated, but only with the early extract.

\section{An early-to-late modulation with the major late transcripts}

To confirm that late nuclear extracts gain new capabili- ties, or at least are very efficient for the splicing of certain pre-mRNA species, we analyzed splicing of major late transcripts, which is known to occur very efficiently during the late period of infection (Nevins and Darnell 1978|. In contrast, during the early period, the transcripts of the major late unit containing the $\mathrm{L} 1, \mathrm{~L} 2$, and $\mathrm{L} 3$ regions as the 3 -terminal exon are not only synthesized at a low level but are also processed with an efficiency between $75 \%$ and $25 \%$ relative to that of the E2 transcription unit (Shaw and Ziff 1980; Nevins and Wilson 1981). We chose two substrates derived from the $5^{\prime}$ region of the late transcription unit, which contain the wild-type 1021-nucleotide IVS or a deleted 234-nucleotide IVS and terminate 87 nucleotides downstream from the $5^{\prime}$-splice site of the second leader (Fig. 3). The substrates are designated ML and ML-i234, respectively. The splicing reaction was assessed by following the accumulation of the 1021-nucleotide IVS (Fig. 3, left) or that of the 234nucleotide IVS (Fig. 3, right). The mRNA is a short species of 228 nucleotides, which is detected in Figure 3 (right) as a diffuse band of 230-215 nucleotides. We have verified by reverse transcription that the bona fide $5^{\prime}$ splice site and branch site (Padgett et al. 1984) are used in our system (data not shown). With an early extract (Fig. 3, lane d) or an "uninfected" extract (Fig. 5, lane i, below), the splicing reaction of the wild-type ML transcript is weak. This is in agreement with data obtained previously in the course of the development of in vitro splicing systems (Hardy et al. 1984). In contrast, the reaction becomes much more efficient with the late extract, as at least $50 \%$ of the substrate is spliced after $2 \mathrm{hr}$ of incubation (Fig. 3, lane f). Decreasing the size of the ML IVS from 1021 to 234 nucleotides (Fig. 3, right) results in an improvement of the splicing reaction with the early nuclear extract, but the reaction is still stimulated with the late extract by a factor of 2.5 . Thus, even if the splicing efficiency of wild-type ML transcript with early nuclear extract is lower than that expected early in infection, the fact that we obtain efficient splicing with late extract may be a good way to follow the "late" abilities of this extract. In addition, the ML splicing reaction and the $9 \mathrm{~S}$ reaction with the Sp4 transcript behave very similarly, and we have analyzed both in the course of our work.

\section{Trans-acting factors involved in the splicing modulation with early and late nuclear extracts}

Two kinds of factors, which may or may not normally be involved in the splicing reaction, may intervene in the modulation of adenoviral splicing: either protein factors, or components containing a nucleic acid moiety essential for their activity. To determine whether nucleic acids are involved, we treated the late nuclear extract with high concentrations of micrococcal nuclease (MNase), which is expected to result in an almost complete hydrolysis of nucleic acids. By complementation experiment, we then analyzed whether this treatment preserves the late characteristics of the extract.

Given that the addition of one-half dose $(5 \mu l)$ of the late extract to one-half dose of the early extract is suffi- 


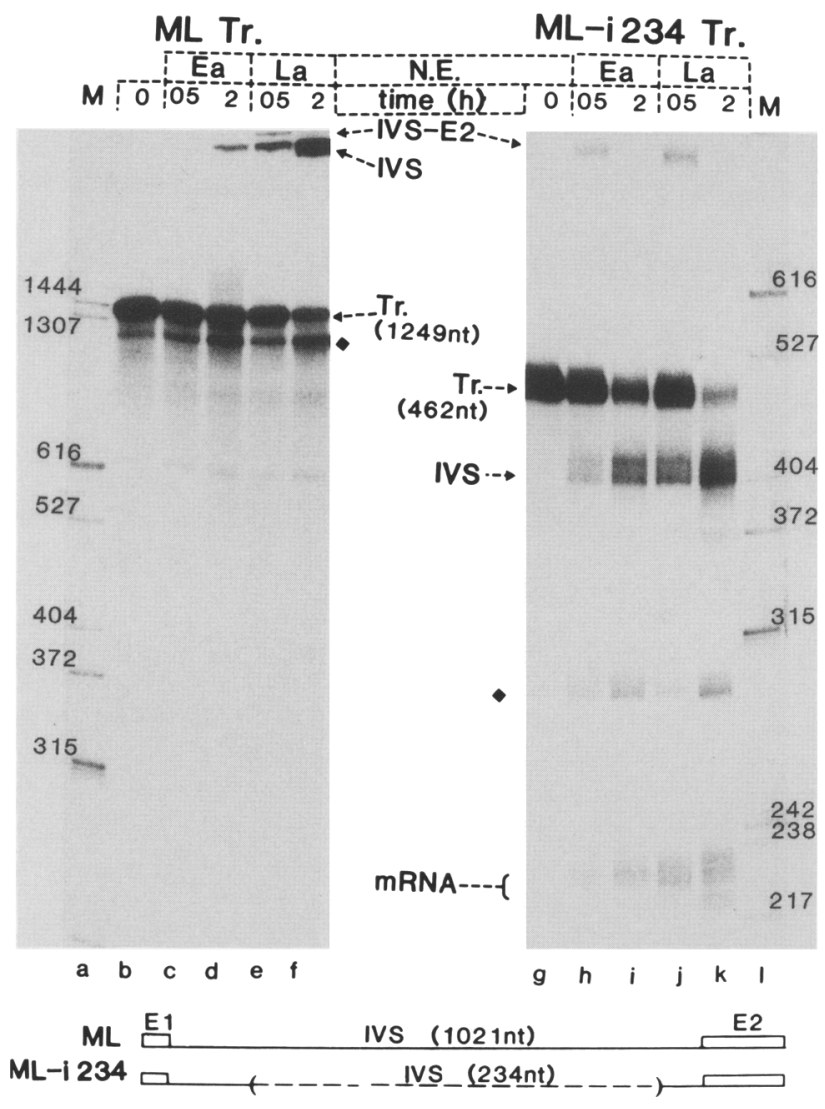

Figure 3. Enhanced in vitro splicing of major late transcripts with late nuclear extracts. Transcripts derived from the $5^{\prime}$ region of the major late transcription unit of adenovirus, containing either the wild-type IVS1 of 1021 nucleotides (ML transcript) or a shortened IVS of 234 nucleotides (ML-i234 transcript), are spliced with early (Ea) and late (La) nuclear extracts, as indicated in the legend to Fig. 2. The positions of the transcripts and the splicing products are indicated between the two panels. For the ML transcript, the part of the autoradiogram that contains the mRNA products is not shown. The structure of the transcripts is schematized at bottom as in Figure 2. The deletion within the ML-i234 transcript is in parentheses. ( Prematurely terminated transcripts. The markers $(\mathrm{M})$ in lanes $a$ and $I$ are labeled MspI and TaqI fragments of pBR322.

cient to induce a twofold inhibition of the $13 \mathrm{~S}$ reaction (Fig. 4, cf. lane g with lanes b and i, respectively), MNasetreated late extract was complemented with an early extract (lane e) and vice versa (lane f), and the splicing abilities of these combinations, compared to controls, were analyzed. We observed that the combination of MNasetreated early extract plus early extract $(\mathrm{MN}-\mathrm{Ea}+\mathrm{Ea}$, lane d) promotes $13 \mathrm{~S}$ mRNA splicing as efficiently as the homologous combination of intact early extract preincubated without MNase (Ea $+\mathrm{Ea}$, lane $\mathrm{c})$. This shows that one-half of the concentration of U snRNPs in an extract mixture is sufficient to obtain an efficient $13 \mathrm{~S}$ splicing reaction. Significantly, the combination of MNase late extract plus early extract ( $\mathrm{MN}-\mathrm{La}+\mathrm{Ea}$, lane e) gives identical splicing to the previous one. In contrast, the converse combination of MNase early extract plus late extract (MN-Ea $+\mathrm{La}$, lane f) results in about a twofold inhibition of the $13 \mathrm{~S}$ splicing efficiency, similar to that observed with the combination of early plus late extracts $(\mathrm{Ea}+\mathrm{La}$, lane $\mathrm{g})$, indicating that the MNase late extract has lost its late character. Thus, the above results strongly suggest that the $13 \mathrm{~S}$ modulation is mediated by a MNase-sensitive component. In agreement with this, the combination of MNase late extract plus late extract ( $\mathrm{MN}-\mathrm{La}+\mathrm{La}$, lane $\mathrm{h}$ ) shows, in comparison to the pure late extract $(\mathrm{La}+\mathrm{La}$, lane i) a partial restoration of the $13 \mathrm{~S}$ reaction. Therefore, this indicates that a twofold reduction of the nuclease-sensitive component partially relieves the $13 \mathrm{~S}$ splicing inhibition.

Analysis of the modulation of the $9 \mathrm{~S}$ reaction is not as easy to follow, as the efficiency of the $9 S$ reaction remains weak, even with the late extract ( $L a ̊ a$ and its simple preincubation without $\mathrm{MNase}(\mathrm{La}+\mathrm{La}$, lane i) still results in a decrease of the splicing efficiency, which is abnormally important in this particular experiment. Because the relative variations of the $9 \mathrm{~S}$ splicing efficiencies with the various combinations of extracts parallel those of the major late splicing reaction (Fig. 4, right), only the latter will be commented on. Analysis of splicing of the ML transcript shows that the early extract plus late extract combination (Ea $+\mathrm{La}$, lane $\mathrm{q}$ ) results in splicing efficiency similar to that of the homogeneous late extract $(\mathrm{La}+\mathrm{La}$, lane $\mathrm{s})$. All combinations including at least one-half dose of intact late extract, as in the MNase late extract plus late extract (MN-La + La, lane $\mathrm{r}$ ) or in the MNase early extract plus late extract (MN$\mathrm{Ea}+\mathrm{La}$, lane $\mathrm{p}$ ), preserve a significant ability to splice the ML transcript, whereas the other combinations (MN$\mathrm{La}+\mathrm{Ea}$ or $\mathrm{MN}-\mathrm{Ea}+\mathrm{Ea}$, lanes o,n) have lost this ability. Therefore, this indicates that a MNase-sensitive component is also required for efficient splicing of the ML substrate. In addition, both MN-Ea + $\mathrm{La}$ and $\mathrm{MN}-\mathrm{La}+\mathrm{La}$ combinations (lanes $p, r$ ) are less efficient than the $\mathrm{Ea}+\mathrm{La}$ combination (lane q), a result that was already observed (see above) for the 9S mRNA reaction. The most likely interpretation is that these two reactions require a normal level of $U$ snRNP for maximal efficiency, which is not the case for the $13 \mathrm{~S}$ mRNA reaction.

\section{Induction of the early-to-late modulation with nucleic acids isolated from nuclear extracts}

To determine whether the nucleic acid moiety of the nuclease-sensitive component plays a direct role in the modulation, we tried to induce the late character to an uninfected or an early nuclear extract by preincubating the extracts with total nucleic acids isolated previously from a late nuclear extract. In these induction experiments, one standard dose $(10 \mu \mathrm{l})$ of uninfected or early extract was preincubated for $15 \mathrm{~min}$ in splicing conditions with nucleic acids isolated from one-half dose of late extract, to mimic a combination of early plus late nuclear extracts. The splicing abilities of these mixtures and of appropriate controls were then analyzed. Preincu- 
Figure 4. MNase-sensitive factor is required for the early-to-late modulation of E1A and ML transcript splicing. Complementation assays were carried out with various combinations of nuclear extracts treated with MNase (as described in Materials and methods) and untreated extracts, in a $1: 1$ ratio. The early (Ea) or late (La) nuclear extracts treated with MNase at $30^{\circ} \mathrm{C}$ for $20 \mathrm{~min}$ are indicated above the lanes with a lune. All the other aliquots of nuclear extracts are also preincubated without enzyme at $30^{\circ} \mathrm{C}$ for $20 \mathrm{~min}$, except the extract aliquots tested in lanes $b, 1$ and $j, t$, designated $E a ̊$ and Lå, respectively, which are not preincubated. The Sp4 (left) and ML transcripts (right) were spliced with the various combinations of nuclear extracts; the products are analyzed as in Figs. 1-3, and the same indications are given. (Left) The upper region of the autoradiogram has been exposed approximately two times more.

bation of early extract with nucleic acids isolated from uninfected $(\mathrm{Ni})$ or early (Ea) extract results-when the splicing assay with $\mathrm{Sp} 4$ transcript is carried out-in a slight decrease of the $13 \mathrm{~S}$ splicing and no change for the 9S mRNA splicing (Fig. 5, lanes c, d). In contrast, the addition of nucleic acids isolated from late (La) nuclear extract (Fig. 5, lane e) results in a 13S-9S splicing modulation, which parallels that obtained with the mixture of early and late extracts, in a $1: 1$ ratio (lane f). The same kind of results are obtained when analyzing splicing of the ML transcript with uninfected extract induced by the addition of various nucleic acid preparations, because only late nucleic acids are able to promote splicing (lane $\mathrm{m}$ ) with an efficiency comparable to that obtained with the mixture of uninfected plus late extracts (lane $n$ ).

Therefore, these data show that the nucleic acid moiety of the nuclease-sensitive components of the late extract is involved primarily in the early-to-late splicing modulation of the E1A and ML transcripts. Because the extent of the 13S-9S modulation might be dependent on the amount of total nucleic acids used for the induction experiments, we asked whether the difference in behavior of the added early or late nucleic acid preparations was not due to a different content in total nucleic acids within both the early and late nuclear extracts. This was not the case because the late extracts contain only 10 $25 \%$ more nucleic acids than the early extracts. In addition, we have verified that a $13 \mathrm{~S}-9 \mathrm{~S}$ modulation similar to that observed with the late nucleic acids may be obtained with early nucleic acids but only when their amount has been increased by a factor of $4-8$, and that nucleic acids isolated from uninfected nuclear extracts are twofold less efficient than early nucleic acids (data not shown). Therefore, this finding indicates that the nucleic acids carrying the induction property are either more efficient or more concentrated in late than in early nuclear extracts.

Significantly, the modulations obtained by the addition of late nucleic acids in the induction experiments (Fig. 5, lanes e, $\mathrm{m}$ ), are very similar to those obtained by making a simple combination of early or uninfected and late nuclear extracts (lanes $\mathbf{f}, \mathbf{n}$ ), suggesting that the molecular events linked to the induction by pure nucleic acids occur in a specific manner.

\section{Characterization of the nucleic acids that induce the E1A modulation}

Because the induction experiments described above seem to be specific, we used this approach for a further

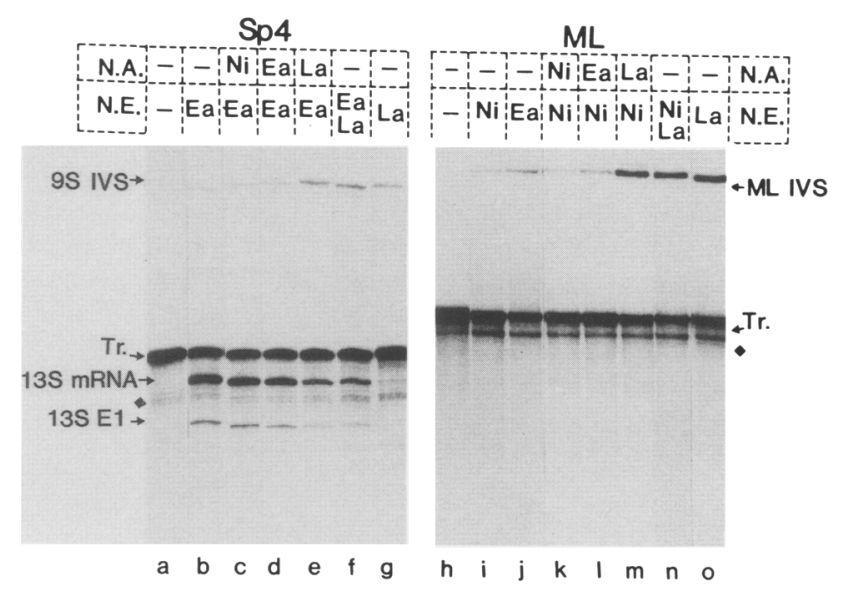

Figure 5. Induction of ElA and ML transcript modulation with nucleic acids isolated from late nuclear extract. Induction experiments were carried out by preincubating $10 \mu \mathrm{l}$ of early (Ea) nuclear extract (left) or control [noninfected (Ni)] nuclear extract (right) with nucleic acids (N.A.) isolated from $5 \mu$ l of noninfected, early, or late nuclear extracts, respectively. After a 15-min preincubation at $30^{\circ} \mathrm{C}$, the $\mathrm{Sp} 4$ transcript (left) or $\mathrm{ML}$ transcript (right) was spliced for $2 \mathrm{hr}$ and the products were analyzed as indicated in Figs. 1-4. In lanes $b$ and $j$, the controls of splicing are given with the early extracts; in lanes $g$ and $o$, those with the late extracts. In lanes $f$ and $n$, the controls of splicing with a combination of early and late extracts are given (lane $f$ ) or of noninfected and late extracts (lane $n$ ) in a 1: 1 ratio. All the aliquots of extracts (with or without inducing nucleic acids) are preincubated at $30^{\circ} \mathrm{C}$ for $15 \mathrm{~min}$. 
analysis of the inducing nucleic acids. To determine their nature, identical aliquots of RNase- or DNasetreated nucleic acids from early (not shown) and late nuclear extracts were used for induction assays (Fig. 6A). The modulation of ElA splicing, detected with untreated late nucleic acids (lane b), is completely lost after RNase treatments, in conditions that eliminate (lane c) or do not eliminate (lane d) double-stranded RNA. In contrast, the modulation is fully retained after DNase treatment (lane e). Therefore, this indicates that the inducing nucleic acids are RNA and that long double-stranded sequences are not primarily involved in the modulation.

To determine whether the inducing RNAs are of viral origin, we tested identical aliquots of RNA selected by hybridization to viral genomic DNA in induction assays

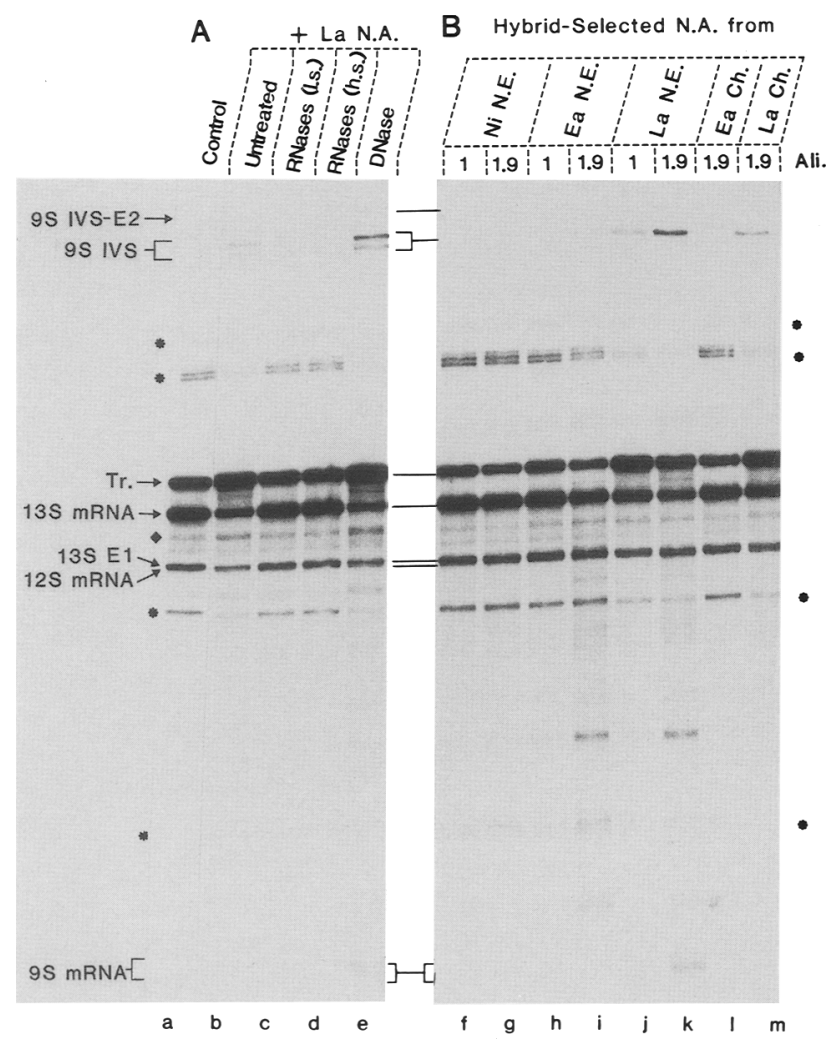

Figure 6. Induction experiments with RNase- or DNasetreated and hybrid-selected nucleic acids. $(A)$ Prior to induction assays with the Sp4 transcript, nucleic acids from late nuclear extract (La N.A.) were treated either with RNases A and T1 in low salt medium (l.s.) or in high salt medium (h.s.) (lanes $c, d$ ) or with DNase (lane $e$ ) as described in Materials and methods. The amount of $0.5 \mu \mathrm{g}$ of each of these samples and of untreated late nucleic acids (lane $b$ ) was tested. A splicing control without late nucleic acids is shown in lane $a$. $(B)$ Nucleic acids (N.A.) from noninfected nuclear extract (Ni N.E.), early nuclear extract (Ea N.E.), or chromatin fraction (Ea Ch.), and late nuclear extract (La N.E.) or chromatin fraction (La Ch.) were selected by hybridization to genomic adenoviral DNA (see Materials and methods). Aliquots (Ali) corresponding to $1 / 13$ and $1 / 7$ of each hybrid-selected RNA ( 1 and 1.9 , respectively) were used for the induction assays. The splicing products are analyzed as in Fig. 1, and the same indications are given.

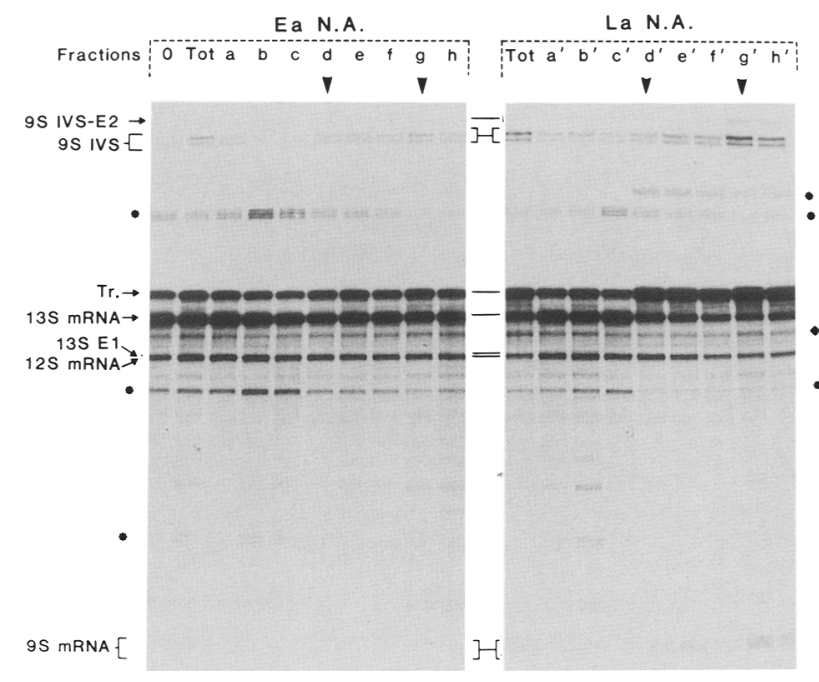

Figure 7. Induction experiments with nucleic acids fractionated on sucrose gradients. After centrifugation on sucrose gradients of $100 \mu \mathrm{g}$ of nucleic acids, isolated from early or late nuclear extracts, 500- $\mu$ l fractions were collected from the top of the gradients and ethanol-precipitated. From three consecutive fractions, $30 \mu \mathrm{l}$ was pooled and tested in induction assays by using the Sp4 transcript, as described in Materials and methods. (Lanes $a-h$ and $a^{\prime}-h^{\prime}$ ) The pooled fractions of early and late nucleic acids, respectively, from top to bottom of the gradient, which were tested for Sp4 splicing. Nonfractionated nucleic acids $(1 \mu \mathrm{g})$ were tested in lanes Tot, and a splicing control without nucleic acids in lane 0 . Arrowheads above lanes $d, d^{\prime}$ and $g$, $g$ indicate the position of $18 \mathrm{~S}$ and $28 \mathrm{~S}$ rRNA on the gradients. The splicing products are analyzed as in Fig. 1.

(Fig. 6B). As expected, no modulation was observed with RNA from uninfected nuclear extracts (lanes $f, g$ ). Aliquots of hybrid-selected RNA from early nuclear extract did not give a clear modulation (lanes $h, i)$. In contrast, the hybrid-selected RNA from late nuclear extract gave a significant modulation (lanes $j, k$ ), which was already detected with the lowest level tested. With the highest level of both early and late viral RNA (lanes i,k), a mild degradation, most likely of the unspliced transcript, was detected as a low radioactive background, but this did not hinder the interpretation of the data. We have also analyzed hybrid-selected RNA from early and late chromatin fractions. The RNA from the late chromatin fraction (lane $\mathrm{m}$ ) also gave a significant modulation of E1A splicing. Thus, these combined data indicate that the in vitro modulation is attributed mainly to an RNA of viral origin.

To obtain information on the size of the inducing RNA, nucleic acids from early and late nuclear extracts have been separated by centrifugation on sucrose gradients. As observed in Figure 7, aliquots of pooled RNA fractions of the early nuclear extract have only a poor capacity to induce the E1A modulation, the $13 \mathrm{~S}$ reaction being only weakly impaired with the RNA of higher size (fractions g,h). However, with the RNA fractions of the late nuclear extract sedimenting faster than 18S rRNA (fractions $\mathrm{e}^{\prime}$ to $\mathrm{h}^{\prime}$ ) the $13 \mathrm{~S}$ reaction was severely inhib- 
ited, whereas the $9 \mathrm{~S}$ reaction was significantly improved. Therefore, these results indicate that the inducing viral RNAs are not low-molecular-weight RNAs, such as prematurely terminated RNA (Mok et al. 1984), but are long transcripts, most probably synthesized from the major late transcription unit.

\section{Discussion}

To analyze in vitro the cis- and trans-acting parameters involved in the modulation of the E1A transcript during the infection cycle, we have prepared nuclear extracts isolated from infected HeLa cells. With these extracts, we were able to reproduce with the wild-type E1A substrate a splicing modulation similar to that occurring during the infection cycle. This is the first example of an in vitro splicing system derived from the same cells, in two different biological states, which successfully mimics the in vivo modulation. In comparison to early extracts, the late nuclear extracts promote a severe inhibition of the 13S mRNA while an important stimulation of the 9S mRNA is obtained. We show with most of the late nuclear extracts that the $9 \mathrm{~S}$ splicing efficiency becomes comparable to or higher than that of the 13S mRNA reaction, a result that resembles the in vivo situation. Clearly, the absolute efficiency for the $9 \mathrm{~S}$ reaction in vitro may be lower than that in vivo, as a substantial number of intact transcripts remain after a 2-hr incubation for splicing. However, it is known that the splicing efficiency of in vitro systems decreases when the size of the intron of the substrates increases. In addition, both $5 '$ - and $3^{\prime}$-splice sites of the $9 S$ intron are suboptimal (see below), and it is likely that the weakness of the splicing signals may have more dramatic consequences in in vitro rather than in vivo systems.

The finding of an in vitro modulation of the $13 \mathrm{~S}$ and $9 \mathrm{~S}$ splicing reactions is the first clue that most of the mechanisms involved in vivo for the splicing and the modulation of the E1A pre-mRNA are not significantly altered during preparation of the nuclear extracts and that they are still functional throughout the in vitro splicing assays. Up to now, attempts to develop in vitro splicing systems prepared from different cell types, which mimic the regulated splicing pattern of cellular genes observed in these cell types, have been rather disappointing (for review, see Latchman 1990|. This was the case for the analyses of calcitonin/CGRP pre-mRNA splicing with nuclear extracts from HeLa and PC12 cells (Bovenberg et al. 1988) and of rat or chicken $\beta$-tropomyosin substrates containing the two mutually exclusive exons and the adjacent exons (Helfman et al. 1988; Goux-Pelletan et al. 1990). With the latter substrates, the existence of secondary structure covering regions of the alternative exons might explain the inefficient specific splicing in vitro (Libri et al. 1989, 1990), as demonstrated previously by Eperon et al. (1988). One group has also shown that the SV40 early pre-mRNA, although not regulated, is spliced differently in human HeLa cells and embryonic kidney 293 cells (Fu and Manley 1987) and that nuclear extracts isolated from these cells faithfully reproduce small $\mathrm{t}$ and large $\mathrm{T}$ splicing observed in vivo (Gè and Manley 1990).

\section{Cis-acting parameters of the E1A substrate involved in the modulation}

The sequences of the 13S, 12S, and 9S $5^{\prime}$-splice sites are CA/GUAAGU, GG/GUGAGG, and AG/GUACUG, respectively. They exhibit a progressively weaker match with the consensus sequence in the following order: $13 \mathrm{~S}>12 \mathrm{~S}>9 \mathrm{~S}$. In addition, the common $3^{\prime}$-splice site, whose sequence is $(\underline{\mathrm{U}})_{6} \mathrm{AAAAG} /$, might be considered to be a poor splice site, as well as the branch site, whose sequence (GUUUAAA) is also far from the consensus sequence. The presence of suboptimal splicing signals within a pre-mRNA subject to alternative splicing is frequent, as expected, as balanced competition between several sites will be facilitated if these sites do not have maximum strength.

For a better understanding of the role of cis-and transacting factors, it is important to identify the "default" pattern of an alternative splicing. For the ElA premRNA, this default pattern is most likely obtained in the early period of infection with a predominant $13 \mathrm{~S}$ reaction and a minor $9 \mathrm{~S}$ reaction. This pattern is also obtained when E1 A transcripts are formed in the absence of late transcripts, which is the case if infection occurs in the presence of protein synthesis inhibitors (Chow et al. 1979) or in HeLa cells transfected with ElA plasmids (Svensson et al. 1983). Our analysis of the splicing of the truncated (Fig. 1) and modified Sp4 transcripts (Fig. 2) shows that the $13 S$ and $12 S$ reactions have a strong cisinhibitory effect on the 9S mRNA reaction during the early period of infection, which accounts for the poor efficiency of the $9 \mathrm{~S}$ mRNA reaction during this period. We also have indications that the $13 \mathrm{~S}$ splicing inhibition is an important event of the modulation of E1A splicing during the early-to-late switch and that it accounts, at least in large part, for the stimulation of the $9 \mathrm{~S}$ reaction during the late period (Fig. 2). For instance, we observe that the $9 \mathrm{~S}$ reaction stimulation is necessarily coupled to an inhibition of the $13 \mathrm{~S}$ reaction, whereas the converse is not true (Fig. 4, lanes $\mathrm{f}-\mathrm{j}$ ).

Our results also suggest that the $5^{\prime}$-splice sites, taken alone, are not sufficient to explain the splicing modulation of E1A transcripts. Interestingly, Ulfendahl et al. (1989) showed that replacing the common 3' region of the ElA alternative intron with a heterologous $3^{\prime}$ region results in a dramatic increase of the use of the 9S 5'splice site. Therefore, it is likely that at a minimum, cooperation between several sites is required to account for the modulation of the splicing of E1A transcripts.

\section{Trans-acting factors involved in the early-to-late modulation of splicing}

Complementation experiments (Fig. 4), as well as induction experiments (Fig. 5), showing that the simple addition of nucleic acids isolated from late nuclear extracts is able to induce a modulation very similar to that obtained 
with the nuclear extracts, strongly suggest that these late nucleic acids, or a specific fraction of them, represent the initial trans-acting factor responsible for the modulation. We have shown that the inducing nucleic acids are RNAs of high molecular weight and that the inducing ability originates mainly, if not exclusively, from viral RNAs, most probably synthesized from the major late transcription unit. This is not unexpected, because late in infection the rate of transcription of this unit increases dramatically; and at this stage up to 50$60 \%$ of the nonribosomal nuclear RNA are of viral origin (Manley et al. 1979; Gattoni et al. 1980; Shaw and Ziff 1980). The accumulation of viral transcripts in the form of unspliced and partially processed molecules (Ziff 1980 and references therein) may result in dramatic consequences for cellular processes that may be rapidly saturated. For instance, the infection of cells with vesicular stomatis virus (VSV) involves a rapid blockage of the maturation of U1 and U2 snRNPs (Fresco et al. 1987; Frielle et al. 1989), most probably caused by a sequestering of $\mathrm{Sm}$ proteins by the 47-nucleotide leader RNA of VSV, which shows sequence homology with the binding target of the U snRNP.

We therefore postulate a similar mechanism of action for the trans-acting factor responsible for the ElA modulation. The accumulation of viral transcripts in the nucleus may result in an extended involvement of the splicing factors (especially the RNA-binding factors); and sequestered factors, which were not initially present in vast excess in the cell, may become limiting. If alternative splicing reactions have different requirements for these factors, their sequestering might result in a modulation of the alternative reactions. Such an indirect mechanism of action for inducing nucleic acids appears to be very plausible for several reasons. First, this mechanism implies a reversibility of the induction when all the nucleic acids of a late extract are hydrolyzed, resulting in a release of the previously sequestered splicing factors. The results of our complementation experiments (Fig. 4) are in full agreement with this statement. Second, the existence of splicing factors (SF2 or ASF) that favor, at high concentration, the use of the $5^{\prime}$-splice site closest to the $3^{\prime}$-splice site when several $5^{\prime}$-splice sites are in competition also strengthens our hypothesis $\mid \mathrm{Ge}$ and Manley 1990; Krainer et al. 1990b). These factors might become limiting during the late period of infection with adenovirus, as ASF factor is rate limiting for the splicing of SV40 early pre-mRNA into the small $t$ mRNA in HeLa cells (Ge and Manley 1990) and SF2 factor has RNA-binding properties in vitro (Krainer et al. 1990a). Interestingly, their limitation might favor a switch from the proximal (13S) to the distal (9S) donor sites (Ge and Manley 1990; Krainer et al. 1990b). This, together with the intrinsic decrease of the $13 \mathrm{~S}$ reaction observed with the Spl transcript (Fig. 1), should result in a strong modulation of the ElA alternative splicing.

Finally, it appears that the proposed mechanism of a sequestering of common factors might not be restricted only to E1A substrates during adenoviral infection but might also concern other alternative splicing reactions in which a choice between several $5^{\prime}$-splice sites occurs. The E1B transcripts (Spector et al. 1978; Montell et al. 1984) and the major late transcripts specific of the Ll body are also subject to similar modulations late in infection (Akusjärvi and Persson 1981; Delsert et al. 1989). The question concerning the precise nature of the viral transcripts initially responsible for all these modulations remains to be answered.

\section{Materials and methods}

\section{Cell growth and extract preparations}

HeLa S3 cells were grown in suspension culture in the presence of $10 \%$ calf serum. Cells from the same batch were infected with purified adenovirus 2 (20-50 plaque-forming units per cell) and were harvested $5,10,12$, or $14 \mathrm{hr}$ postinfection. Nuclear and cytoplasmic S-100 extracts were prepared as described previously (Dignam et al. 1983; Schmitt et al. 1987). The residual nuclear pellet of infected cells, defined as the chromatin fraction, has been also used as a source of RNA.

\section{Plasmid constructions}

The plasmids $\mathrm{Sp} 4$ and $\mathrm{Spl}$ contain the natural E1A sequences from positions 533 to 1342 ( $\mathrm{XbaI}$ site) of the genome or the $X m a I-X b a I$ fragment (from positions 1006 to 1342 ), respectively, inserted in the polylinker of the pSP65. The 13S 5'-splice site ( $19 \mathrm{bp}$ from positions 1101 to 1019 ) and $12 \mathrm{bp}$ in the polylinker were deleted from Sp4 $\Delta 13$. Sp4 $\Delta 13-12$ was derived from $\mathrm{Sp} 4 \Delta 13$ by an additional deletion of the BstXI-SmaI sequences (between positions 934 and 1008), that removed the 12S 5'splice site at position 974. Spl-13, Spl-12, and Sp1-9 are constructed from Sp1 plasmid first by replacing a 17-bp sequence encompassing the $13 \mathrm{~S} 5$ '-splice site with a polylinker sequence of $21 \mathrm{bp}$. Second, 34- to 39-bp fragments encompassing the 13S, $12 \mathrm{~S}$, or $9 \mathrm{~S} 5$ '-splice sites were reinserted within the 21 -bp polylinker.

The ML plasmid was obtained by insertion of the $5^{\prime}$ part of the major late transcription unit, from the PvuII to $B s p$ MII sites (positions $6072-7259$ of the genome) into the polylinker of pGEM-1 vector. The transcript synthesized from the plasmid consists of a chimeric leader 1 of 48 nucleotides similar to the natural leader, the intact first IVS (1021 nucleotides), an exon 2 including the natural leader 2 , and the following 87 -nucleotide intronic sequence of IVS2. In the ML-i234 transcript, the central region of the IVS $(787 \mathrm{bp})$, between the HindIII and BstEII sites (positions 6235 and 7021) was deleted, resulting in an IVS of 234 bp. The $\beta$-globin plasmid contains the PuvII-BglII fragment of the rabbit $\beta$-globin gene present in $\mathrm{pEP1}$ plasmid, from position -9 to 1201 relative to the mRNA cap site (Rautmann et al. 1984), inserted in the polylinker of pSP64 vector.

\section{RNA synthesis and in vitro splicing}

In vitro transcription of linearized DNA templates was performed with SP6 polymerase. The labeled capped RNAs were synthesized in the presence of $\left[\alpha^{-32} \mathrm{P}\right]$ CTP $(\sim 470 \mathrm{Ci} / \mathrm{mmole})$ and purified as described previously (Schmitt et al. 1987). Standard splicing reactions were carried out as described previously in $25-\mu \mathrm{l}$ assays containing $10 \mu \mathrm{l}$ of nuclear extract, $50,000 \mathrm{cpm}$ of labeled substrate corresponding to $\sim 2 \mathrm{ng}$ of RNA, $2.1 \mathrm{~mm}$ $\mathrm{MgCl}_{2}, 42 \mathrm{mM} \mathrm{KCl}, 0.6 \mathrm{~mm}$ ATP, $20 \mathrm{~mm}$ creatine phosphate, and $3.2 \%$ (wt/vol) polyvinylalcohol (Schmitt et al. 1987). The assays were incubated at $30-31^{\circ} \mathrm{C}$ for the indicated times, and 
the RNAs were purified as described previously. The products of the reactions were analyzed on denaturing $5 \%$ polyacrylamide gels (30:1 acrylamide/bisacrylamide) in $8 \mathrm{~m}$ urea.

\section{Complementation and induction analysis}

MNase digestion of nuclear extracts was performed with MNase $\left(1870 \mathrm{U} / \mathrm{ml}\right.$ of extract) in the presence of $1 \mathrm{mM} \mathrm{CaCl}_{2}$, for $20 \mathrm{~min}$ at $30^{\circ} \mathrm{C}$. The digestion was stopped by chelation of $\mathrm{Ca}^{2+}$ with 2 mM EGTA. The treated extracts were then complemented with nontreated extract in a $1: 1$ ratio, and the splicing abilities of the mixtures were analyzed. For the induction experiments, nucleic acids were purified from nuclear extracts by digestion with proteinase $\mathrm{K}$ in the presence of SDS, followed by deproteinizations, as described previously (Schmitt et al. 1987). In the induction assay $10 \mu \mathrm{l}$ of nuclear extract of uninfected or early infected cells was preincubated with nucleic acids isolated from $5 \mu \mathrm{l}$ of early or late nuclear extracts at $30^{\circ} \mathrm{C}$ for 10-15 min, in splicing conditions. The splicing was then carried out by the addition of the labeled substrate and incubation at $30^{\circ} \mathrm{C}$ for $2 \mathrm{hr}$. The labeled RNA products were analyzed as described above.

\section{Nucleic acid analysis}

Prior to certain induction experiments, nucleic acids isolated from nuclear extracts of uninfected, early, or late infected cells were submitted to various treatments. RNase or DNase treatment was as follows: $10 \mu \mathrm{g}$ of nucleic acids were dissolved either in $25 \mu \mathrm{l}$ of low salt medium [ $10 \mathrm{~mm}$ Tris- $\mathrm{HCl}(\mathrm{pH} 7.6) ; 1$ mM EDTA] and denatured at $90^{\circ} \mathrm{C}$, or in $25 \mu$ l of high salt medium [10 mM Tris- $\mathrm{HCl}(\mathrm{pH} 7.6) ; 200 \mathrm{~mm} \mathrm{NaCl}]$. Both assays were digested with $0.15 \mu \mathrm{g}$ of RNase A and 7.5 units of RNase $\mathrm{T} 1$ for $20 \mathrm{~min}$ at $30^{\circ} \mathrm{C}$. For DNase treatment, the nucleic acids were dissolved in $25 \mu$ l of a medium containing $12 \mathrm{mM}$ Tris- $\mathrm{HCl}$ (pH 7.6), $6 \mathrm{mM} \mathrm{MgCl}_{2}$, and digested with $0.15 \mu \mathrm{g}$ of RNase-free DNase, in the presence of $8 \mathrm{~mm}$ vanidyl ribonucleoside complex and 25 units of RNasin, for $20 \mathrm{~min}$ at $30^{\circ} \mathrm{C}$. All assays were deproteinized as described above.

The hybrid selection assays were performed according to Jagus (1987), with only minor modifications. One hundred micrograms of RNA of uninfected, early and late nuclear extracts were hybridized overnight at $48^{\circ} \mathrm{C}$ to $20 \mu \mathrm{g}$ of genomic adenovirus DNA immobilized on nylon membrane /Gene Screen Plus). After extensive washings, the viral RNA was eluted twice with $150 \mu \mathrm{l}$ of boiling medium containing $2 \mathrm{~mm}$ EDTA and $0.1 \%$ SDS, deproteinized, and ethanol-precipitated in the presence of $3 \mu \mathrm{g}$ of glycogen.

For the RNA fractionation on sucrose gradients, $100 \mu \mathrm{g}$ of nucleic acids from early or late nuclear extracts, dissolved in a medium containing $5 \mathrm{mM}$ Tris- $\mathrm{HCl}(\mathrm{pH} 7.4), 2.5 \mathrm{mM}$ EDTA, and $0.75 \%$ SDS, was denatured for $10 \mathrm{~min}$ at $70^{\circ} \mathrm{C}$. The RNA was layered onto $20-5 \%$ sucrose gradients, in the same medium as described above and centrifuged at 30,000 rpm (SW41 rotor) for $12 \mathrm{hr}$ at $20^{\circ} \mathrm{C}$. Twenty-six fractions were collected. For induction assays, these fractions were pooled by three (starting from the topl, and aliquots were used. rRNA was used as marker.

\section{Acknowledgments}

We are grateful to Dr. P. Simpson and T. Lufkin for critical reading of the manuscript. We thank G. Hildwein for excellent technical assistance, the cell culture group for growing HeLa cells, A. Staub and F. Ruffenach for synthesizing the oligonucleotides, and the secretarial staff and B. Boulay for preparation of the manuscript and the figures. This work was supported by grants from Centre National de la Recherche Scientifique, Institut National de la Recherche Médicale, the Association pour la Recherche sur le Cancer, and the Fondation pour la Recherche Médicale.

The publication costs of this article were defrayed in part by payment of page charges. This article must therefore be hereby marked "advertisement" in accordance with 18 USC section 1734 solely to indicate this fact.

\section{References}

Aebi, M., H. Hornig, R.A. Padgett, J. Reiser, and C. Weissmann. 1986. Sequence requirements for splicing of higher eukaryotic nuclear pre-mRNA. Cell 47: 555-565.

Akusjärvi, G. and H. Persson. 1981. Controls of RNA splicing and termination in the major late adenovinus transcription unit. Nature 292: 420-426.

Arrigo, S. and K. Beemon. 1988. Regulation of Rous sarcoma virus RNA splicing and stability. Mol. Cell. Biol. 8: 4858-4867.

Bach, M., A. Krol, and R. Lührmann. 1990. Structure-probing of U1 snRNPs gradually depleted of the U1-specific proteins A, $\mathrm{C}$ and $70 \mathrm{k}$. Evidence that $\mathrm{A}$ interacts differentially with developmentally regulated mouse U1 snRNA variants. Nucleic Acids Res. 18: 449-457.

Bell, L.R., J.I. Horabin, P. Shedi, and T.W. Clinet. 1991. Positive autoregulation of sex-lethal by alternative splicing maintains the female determined state in Drosophila. Cell 65: 229-239.

Berk, A.J. and P.A. Sharp. 1978. Structure of the adenovirus 2 early mRNAs. Cell 14: 695-711.

Boggs, R.T., P. Gregor, R. Idriss, J.M. Belote, and M. McKeown. 1987. Regulation of sexual differentiation in D. melanogaster via alternative splicing of RNA from the transformer gene. Cell 50: 739-747.

Bovenberg, R.A.L., G.J. Adema, H.S. Jansz, and P.D. Baas. 1988. Model for tissue specific calcitonin/CGRP-I RNA processing from in vitro experiments. Nucleic Acids Res. 16: 95139526.

Breitbart, R.E., A. Andreadis, and B. Nadal-Ginard. 1987. Alternative splicing: A ubiquitous mechanism for the generation of multiple protein isoforms from single genes. Annu. Rev. Biochem. 56: 467-495.

Burtis, K.C. and B.S. Baker. 1989. Drosophila doublesex gene controls somatic sexual differentiation by producing alternatively spliced mRNAs encoding related sex-specific polypeptides. Cell 56: 997-1010.

Chebli, K., R. Gattoni, P. Schmitt, G. Hildwein, and J. Stévenin. 1989. The 216-nucleotide intron of the E1A pre-mRNA contains a hairpin structure that permits utilization of unusually distant branch acceptors. Mol. Cell. Biol. 9: 4852-4861.

Chow, L.T., T.R. Broker, and J.B. Lewis. 1979. Complex splicing patterns of RNAs from the early regions of adenovirus-2. $J$. Mol. Biol. 134: 265-303.

Cooper, T.A. and C.P. Ordahl. 1985. A single cardiac troponin T gene generates embryonic and adult isoforms via developmentally regulated alternative splicing. I. Biol. Chem. 260: 11140-11148.

- 1989. Nucleotide substitutions within the cardiac troponin $\mathrm{T}$ alternative exon disrupt pre-mRNA alternative splicing. Nucleic Acids Res. 17: 7905-7921.

Crenshaw III, E.B., A.F. Russo, L.W. Swanson, and M.G. Rosenfeld. 1987. Neuron-specific alternative RNA processing in transgenic mice expressing a metallothionein-calcitonin fusion gene. Cell 49: 389-398. 
Delsert, C., N. Morin, and D.F. Klessig. 1989. Cis-acting elements and a trans-acting factor affecting alternative splicing of adenovirus L1 transcripts. Mol. Cell. Biol. 9: 4364-4371.

Dignam, J.D., R.M. Lebovitz, and R.G. Roeder. 1983. Accurate transcription initiation by RNA polymerase II in a soluble extract from isolated mammalian nuclei. Nucleic Acids Res. 11: 1475-1489.

Eperon, L.P., I.R. Graham, A.D. Griffiths, and I.C. Eperon. 1988. Effects of RNA secondary structure on alternative splicing of pre-mRNA: Is folding limited to a region behind the transcribing RNA polymerase? Cell 54: 393-401.

Fresco, L.D., M.G. Kurilla, and J.D. Keene. 1987. Rapid inhibition of processing and assembly of small nuclear ribonucleoproteins after infection with vesicular stomatitis virus. Mol. Cell. Biol. 7: 1148-1155.

Frielle, D.W., P.B. Kim, and J.D. Keene. 1989. Inhibitory effects of vesicular stomatitis virus on cellular and influenza viral RNA metabolism and protein synthesis. Virology 172: 274 284.

Fu, X.-Y. and J.L. Manley. 1987. Factors influencing alternative splice site utilization in vivo. Mol. Cell. Biol. 7: 738-748.

Gattoni, R., J. Stévenin, and M. Jacob. 1980. Comparison of the nuclear ribonucleoproteins containing the transcripts of adenovirus-2 and HeLa cell DNA. Eur. J. Biochem. 108: 203211.

Gattoni, R., P. Schmitt, and J. Stévenin. 1988. In vitro splicing of adenovirus E1A transcripts: Characterization of novel reactions and of multiple branch points abnormally far from the 3' splice site. Nucleic Acids Res. 16: 2389-2409.

Ge, H. and J.L. Manley. 1990. A protein factor, ASF, controls cell-specific alternative splicing of SV40 early pre-mRNA in vitro. Cell 62: 25-34.

Goralski, T.J., J.-E. Edström, and B.S. Baker. 1989. The sex determination locus transformer-2 of Drosophila encodes a polypeptide with similarity to RNA binding proteins. Cell 56: 1011-1018.

Goux-Pelletan, M., D. Libri, Y. d'Aubenton-Carafa, M. Fiszman, E. Brody, and J. Marie. 1990. In vitro splicing of mutually exclusive exons from the chicken $\beta$-tropomyosin gene: Role of the branch point location and very long pyrimidine stretch. EMBO I. 9: 241-249.

Hardy, S.F., P.J. Grabowski, R.A. Padgett, and P.A. Sharp. 1984. Cofactor requirements of splicing of purified messenger RNA precursors. Nature 308: 375-377.

Helfman, D.M., S. Cheley, E. Kuismanen, L.A. Finn, and Y. Yamawaki-Kataoka. 1986. Nonmuscle and muscle tropomyosin isoforms are expressed from a single gene by alternative RNA splicing and polyadenylation. Mol. Cell. Biol. 6: 35823595.

Helfman, D.M., W.M. Ricci, and L.A. Finn. 1988. Alternative splicing of tropomyosin pre-mRNAs in vitro and in vivo. Genes \& Dev. 2: 1627-1638.

Hodgkin, J. 1989. Drosophila sex determination: A cascade of regulated splicing. Cell 56: 905-906.

Jagus, R. 1987. Hybrid selection of mRNA and hybrid arrest of translation. Methods Enzymol. 152: 567-573.

Krainer, A.R., G.C. Conway, and D. Kozak. 1990a. Purification and characterization of pre-mRNA splicing factor SF2 from HeLa cells. Genes \& Dev. 4: 1158-1171.

Krainer, A.R., G.C. Conway, and D. Kozak. 1990b. The essential pre-mRNA splicing factor SF2 influences 5 ' splice site selection by activating proximal sites. Cell 62: $35-42$.

Latchman, D.S. 1990. Cell-type-specific splicing factors and the regulation of alternative RNA splicing. New Biol. 2: 297303.

Leff, S.E., M.G. Rosenfeld, and R.M. Evans. 1986. Complex tran- scriptional units: diversity in gene expression by alternative RNA processing. Annu. Rev. Biochem. 55: 1091-1117.

Leff, S.E., R.M. Evans, and M.G. Rosenfeld. 1987. Splice commitment dictates neuron-specific alternative RNA processing in calcitonin/CGRP gene expression. Cell 48: 517-524.

Libri, D., M. Lemonnier, T. Meinnel, and M.Y. Fiszman. 1989. A single gene codes for the $\beta$ subunit of smooth and skeletal muscle tropomyosin in the chicken. I. Biol. Chem. 264: 2935-2944.

Libri, D., M. Goux-Pelletan, E. Brody, and M.Y. Fiszman. 1990. Exon as well as intron sequences are cis-regulating elements for the mutually exclusive alternative splicing of the $\beta$ tropomyosin gene. Mol. Cell. Biol. 10: 5036-5046.

Manley, J.L., P.A. Sharp, and M.L. Gefter. 1979. RNA synthesis in isolated nuclei: Identification and comparison of adenovirus 2 encoded transcripts synthesized in vitro and in vivo. I. Mol. Biol. 135: 171-197.

Mok, M., A. Maderious, and S. Chen-Kiang. 1984. Premature termination by human RNA polymerase II occurs temporally in the adenovirus major late transcriptional unit. Mol. Cell. Biol. 4: 2031-2040.

Montell, C., E.F. Fisher, M.H. Caruthers, and A.J. Berk. 1984. Control of adenovirus E1B mRNA synthesis by a shift in the activities of RNA splice sites. Mol. Cell. Biol. 4: 966-972.

Nevins, J.R. and J.E. Darnell, Jr. 1978. Steps in the processing of Ad2 mRNA: Poly $(\mathrm{A})^{+}$nuclear sequences are conserved and poly(A) addition precedes splicing. Cell 15: 1477-1493.

Nevins, J.R. and M.C. Wilson. 1981. Regulation of adenovirus-2 gene expression at the level of transcriptional termination and RNA processing. Nature 290: 113-118.

Padgett, R.A., M.M. Konarska, P.J. Grabowski, S.F. Hardy, and P.A. Sharp. 1984. Lariat RNA's as intermediates and products in the splicing of messenger RNA precursors. Science 225: 898-903.

Rautmann, G., H.W.D. Matthes, M.J. Gait, and A. Breathnach. 1984. Synthetic donor and acceptor splice sites function in an RNA polymerase $\mathrm{B}(\mathrm{II})$ transcription unit. EMBO $J$. 3: 2021-2028.

Schmitt, P., R. Gattoni, P. Keohavong, and J. Stévenin. 1987. Alternative splicing of E1A transcripts of adenovirus requires appropriate ionic conditions in vitro. Cell 50: 31-39.

Sharpe, N.G., D.G. Williams, P. Norton, and D.S. Latchman. 1989. Expression of the $\mathrm{SmB}^{\prime}$ splicing protein in rodent cells capable of following an alternative RNA splicing pathway. FEBS Lett. 243: 132-136.

Shaw, A.R. and E.B. Ziff. 1980. Transcripts from the adenovirus-2 major late promoter yield a single early family of $3^{\prime}$ coterminal mRNAs and five late families. Cell 22: 905-916.

Smith, C.W.J. and B. Nadal-Ginard. 1989. Mutually exclusive splicing of $\alpha$-tropomyosin exons enforced by an unusual lariat branch point location: Implications for constitutive splicing. Cell 56: 749-758.

Smith, C.W.J., J.G. Patton, and B. Nadal-Ginard. 1989. Alternative splicing in the control of gene expression. Annu. Rev. Genet. 23: 527-577.

Spector, D.J., M. McGrogan, and H.J. Raskas. 1978. Regulation of the appearance of cytoplasmic RNAs from region 1 of the adenovirus 2 genome. J. Mol. Biol. 126: 395-414.

Streuli, M. and H. Saito. 1989. Regulation of tissue-specific alternative splicing: Exon-specific cis-elements govern the splicing of leukocyte common antigen pre-mRNA. EMBO $J$. 8: 787-796.

Svensson, C., U. Pettersson, and G. Akusjärvi. 1983. Splicing of adenovirus- 2 early region $1 \mathrm{~A}$ mRNAs is non-sequential. $I$. Mol. Biol. 165: 475-499.

Ulfendahl, P.J., J.-P. Kreivi, and G. Akusjärvi. 1989. Role of the 
branch site/3'-splice site region in adenovirus-2 E1A premRNA alternative splicing: Evidence for $5^{\prime}$ - and $3^{\prime}$-splice site co-operation. Nucleic Acids Res. 17: 925-938.

Wieczorek, D.F., C.W.J. Smith, and B. Nadal-Ginard. 1988. The rat $\alpha$-tropomyosin gene generates a minimum of six different mRNAs coding for striated, smooth, and nonmuscle isoforms by alternative splicing. Mol. Cell. Biol. 8: 679-694.

Wilson, M.C. and J.E. Darnell Jr. 1981. Control of messenger RNA concentration by differential cytoplasmic half-life adenovirus messenger RNAs from transcription units $1 \mathrm{~A}$ and 1B. I. Mol. Biol. 148: 231-251.

Zhuang, Y. and A.M. Weiner. 1986. A compensatory base change in U1 snRNA suppresses a $5^{\prime}$ splice site mutation. Cell 46: 827-835.

Ziff, E.B. 1980. Transcription and RNA processing by DNA tumor virus. Nature 287: 491-499. 


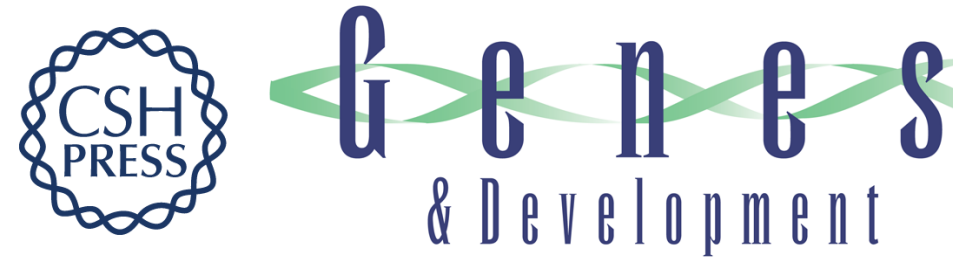

\section{Modulation of alternative splicing of adenoviral E1A transcripts: factors involved in the early-to-late transition.}

R Gattoni, K Chebli, M Himmelspach, et al.

Genes Dev. 1991, 5:

Access the most recent version at doi:10.1101/gad.5.10.1847

References This article cites 58 articles, 15 of which can be accessed free at:

http://genesdev.cshlp.org/content/5/10/1847.full.html\#ref-list-1

License

Email Alerting

Service

Receive free email alerts when new articles cite this article - sign up in the box at the top right corner of the article or click here.

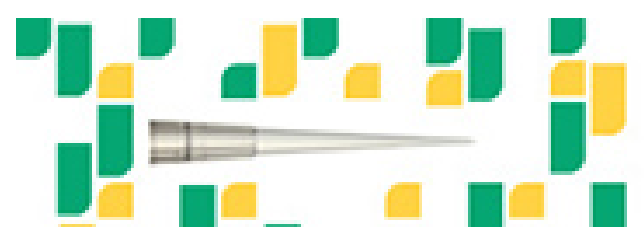

Focused on your science. 